above raiding a ward sister's blanket store-with the best of intentions.

Always a Bible Christian, Grenfell came to regret his youthful assertiveness and to recognise in others the pre-eminence of character over creed. By selecting for competence he created a health service that would pass amenably into secular control long after his death in 1940.

In 1911 work began on the King George V Institute in St John's, a building offering facilities to travellers and safe lodging for girls working as ships' cooks. The king, connected by transatlantic cable, pressed a button in Buckingham Palace to lay the foundation stone on the day of his coronation. (A man was concealed under Grenfell's platform, ready to release the stone if the royal signal failed.) In 1912 the International Grenfell Association was founded and this continues to fund research projects.

The climax of Grenfell's career, and his knighthood, came in 1927, with the rebuilding, in brick, of the St Anthony Hospital as a centre of excellence, with 80 beds. When he retired there were six hospitals, seven nursing stations, four hospital ships, two orphanages, two large schools, 14 industrial centres, and a cooperative lumbermill in the region he served. And beri-beri had disappeared from Labrador.

\title{
The Amazons within: women in the BMA 100 years ago
}

\section{Tara Lamont}

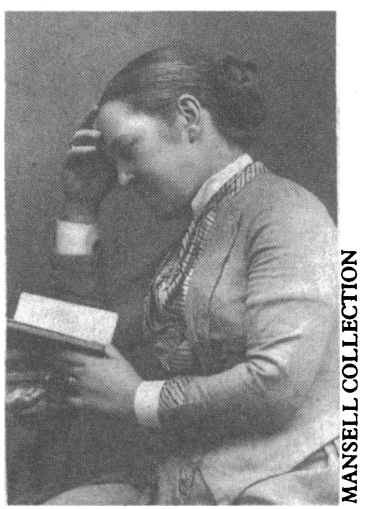

Elizabeth Garrett Anderson in 1889- "the essentially conservative pioneer who represented the acceptable face of practising women doctors to the (male) profession"
British Medical Association, London WC1H 9JR

Tara Lamont, secretary,

board of science and education

BMF 1992;305:1529-32
Shall the Association decide to commit, in a moment of reactionary excitement, an act of hostility in itself useless and sure to be hereafter regretted, against a movement the strength and vitality of which cannot be doubted?' Elizabeth Garrett Anderson addressing the Representative Body in Bath, 1878

In 1892 the British Medical Association voted overwhelmingly to expunge a clause from its articles of association that debarred membership to women. Elizabeth Garrett Anderson had for 19 years been the sole woman member of the association during a stormy period in which the objective of full membership for qualified women doctors often seemed elusive. Editorials in the British Medical fournal and the Lancet had warned against the lowering in status that would ensue from the acceptance of women into the professional body of doctors. There were further fears about entry into the social networks provided by the BMA as the "club" for doctors. A Dr Wade, proposing the motion to exclude women from the association at the annual meeting in Nottingham in 1878, stated that "Even those persons who were most confident there were ladies capable of practising medicine and surgery would admit that it did not necessarily follow that they should become members of this Association, which was, in fact, a movable scientific and social club."'

\section{Isolation and professional status}

In 1873 Elizabeth Garrett (afterwards Elizabeth Garrett Anderson) was accepted for membership by the Paddington branch of the BMA, sponsored by a physician at the Middlesex Hospital and another at St Mary's Hospital. She was accepted by default, there being at that time no stipulation as to the sex of members in the rules and regulations of the association for the simple reason that it was assumed that all medical practitioners were men. ${ }^{2}$ Elizabeth Garrett had become a qualified practitioner by a tortuous route, finally obtaining an MD from Paris in 1870, ten years after attaching herself to Middlesex Hospital as an aspirant medical student. She was refused formal admission to medical schools and instead pursued her studies privately in Edinburgh, St Andrews and London with extensive financial support from her father. The solitary mode of training was difficult: in 1864 she wrote to Emily Davies (later the founder Mistress of Girton College, Cambridge): "Snubbing. . . is unpleasant and for a time hindering. You cannot at once believe that personal effort can altogether make up for the help that teaching and guidance give other students. . . I must peg away alone and do as well as I can." 3
The sense of isolation experienced by Elizabeth Garrett was not only personally difficult but also politically weakening. In her letters to friends and colleagues, Elizabeth Garrett stated the need to open the way for other women doctors - "the cause" as she once called it - rather than just to achieve the individual objective of her qualification. Similarly, she was aware that the headway she made with individual physicians would be no substitute for change in the institutions and bodies that determined professional standards and rights. She wrote in 1862 that "The general feeling seems to be that each doctor is willing to help me privately and singly, but they are afraid to countenance the movement by helping me in their collective capacity.

It was therefore important to Elizabeth Garrett to secure professional status rather than simply to practise as a doctor. She received the Licence of the Society of Apothecaries in October 1865, and in September 1866 her name was placed on the Medical Register. She started practising at the St Mary's Dispensary for Women and Children in Marylebone, where she worked until moving to Paris to 1869 a study for her MD. It was not until 1873 that she applied for ordinary membership to the BMA through the Paddington branch.

\section{Storm over women members}

Two years passed before the fact of her membership became widely known. At the annual representatives meeting in Edinburgh in $187 \overline{5}$ Elizabeth Garrett Anderson was due to read a paper in the obstetrical section. The question of women members of the BMA erupted into a unholy storm. Professor Christison was president at that time and declared his own antagonism towards medical women. A motion was put by $\mathrm{Dr}$ Pemberton proposing a vote on the question of admitting women members to the association. In a letter to her husband Elizabeth Garrett Anderson wrote that she had been advised by Ernest Hart, editor of the British Medical Fournal, to "be on the watch for Pemberton's motion and be ready to speak against it."' Her earlier clashes with the medical profession in the years leading up to qualification had not hardened her to the trials of intense scrutiny and even hostility: "I don't want to fail as a leader even of a forlorn hope but it grates against my taste making anything of a selfdefensive speech to such a body.",

In this climate, the act of reading a scientific paper on obstetrics became politically charged. This was recognised by Anderson herself: "I do hope it [her paper] will be useful in a solid way to the cause." ${ }^{3}$ She 
hoped to defuse the political by establishing her scientific credentials. She wrote to her husband of the "great triumph" of her paper; it was very well received by a large audience, and a vote of thanks was passed by acclamation.

However, the triumph was short lived. A resolution was carried by the annual meeting to hold a referendum on the question of women members: out of 4161 replies, 3072 were against admitting qualified women and 1051 were in favour. Despite a majority of over two to one, this vote had no legal force; however, the results were used in effect to prevent the future admission of women to the BMA.

It was decided that Elizabeth Garrett Anderson's election to the BMA was legal and could not be annulled. Her colleague Frances Hoggan, who was at the time the only other women member of the association, was disenfranchised as she was not registered at the time; a hundred men in the same plight were re-elected.

The political temperature was raised a few years later when a letter appeared in the British Medical Fournal from a Dr Wilson Fox, who had asked the secretary of the BMA whether women were to be admitted. He was given the careful answer that "the Committee of Council have no power to prevent ladies who are members of the Association from attending the meetings of the Association." Dr Fox resigned and asked that the constitution of the association be changed to exclude women so that "the rules of propriety and delicacy... between the sexes" be maintained. ${ }^{5}$ An editorial on 16 February 1878 advised the "two lady members" (Elizabeth Garrett Anderson and Frances Hoggan) to act on the results of the plebiscite and stated that they should "feel called upon to respect that voice and retire from the Society which had declared that their presence was unacceptable."

\section{Women excluded}

In March 1878, an extraordinary general meeting of the association was held in Birmingham to discuss admission of women. A resolution was put forward to a second special meeting in September 1878 during the annual meeting in Bath proposing to add a clause to the articles of the association: that no female shall be eligible as a member of the Association." This was moved by Dr Wade and seconded by Dr Stewart "as the original culprit" who had proposed Elizabeth Garrett Anderson as a member of the Paddington

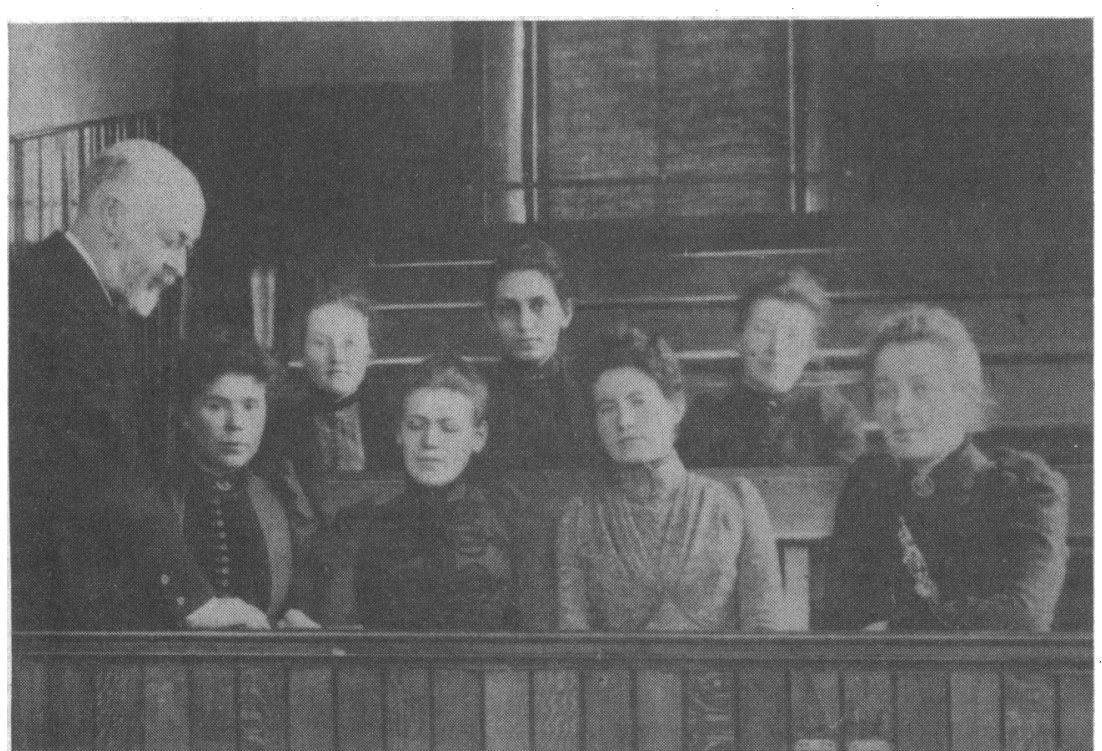

Soon to be doctors-and eligible to join the BMA. Women medical students at Glasgow Royal Infirmary before the turn of the century
Branch of the BMA. However, he bowed to "the strong preponderance of feeling against the admission of ladies" in "the majority of the members."

A lively account is given of the ensuing debate in the British Medical fournal of 17 August 1878. Dr Kerr was given a fairly hostile reception for his short speech in favour of the admission of women, stating "How could that be immodest in a female physician which was modest in a female nurse? [Cries of 'Question']' After a few more interjections, Elizabeth Garrett Anderson spoke and "was received with loud cheering." In an earlier letter to her husband, she had declared her intention to "lift the question on to a higher plane and to appeal to the best part of their minds." ${ }^{\prime 3}$ This she did by a careful and deliberately impersonal speech, which seems from the reports to be punctuated by spontaneous cheers.

Elizabeth Garrett Anderson began her speech with a reminder of the primary function of the association:

We have heard a good deal of this Association being described as a "club", a club for social purposes, and so on. But this is not what it states itself to be in its Articles of Association. There we see that the object or purpose of the Association is twofold: 1. The promotion of medical science; and 2 . The promotion of the interests of the profession. With regard to the first of these objects, no one can venture to say that medical science will be promoted by excluding from the Association a body of honest and painstaking workers, who will bring to the study of many important problems some experience of their own essentially different from that of male practitioners."

The latter point was a key argument used by those campaigning for the rights of women doctors. Elizabeth Blackwell, the American MD, highlighted the function of women doctors in improving the lot of women patients, sparing them the "indelicacy" of encounters with their male counterparts. This argument was seen as politically acceptable, and there is much debate in the letters of Elizabeth Garrett Anderson on the question of whether women should treat men. This was seen as controversial, and an issue that Anderson often avoided in public debate.

\section{No joy at 1878 ARM}

At the 1878 annual representatives meeting she proceeded to argue the case for inclusion of women on the grounds that practising women doctors who were not bound by professional codes and agreements on terms and conditions would weaken the negotiating stance of the association. This is interesting, as correspondence and editorials in the Lancet and British Medical fournal had cautioned against the inclusion of women on the grounds that it would lead to diminishing status and remuneration for doctors. Anderson turned this argument on its head, emphasising the greater control of women afforded by a decision to admit women members:

"You do not want women to be willing to do any amount of work for the lowest prices; you do not want them to be insensible to the general pecuniary interests of the profession; you do not wish them to disregard the courtesies of medical etiquette; and how can you look for a spirit in them of comradeship and of regard for the common weal, if you refuse to let them remain in anything like fellowship with you as members of your Association, and if you go out of your way to create in them a spirit of antagonism and of self-assertion?"'

She played astutely on fears of an unregulated body of women doctors not bound by any professional ethos. The London School of Medicine for Women had opened in 1874 and, although its long term future was still somewhat uncertain at the time of the 1878 annual meeting in Bath, there was in existence at least a body 


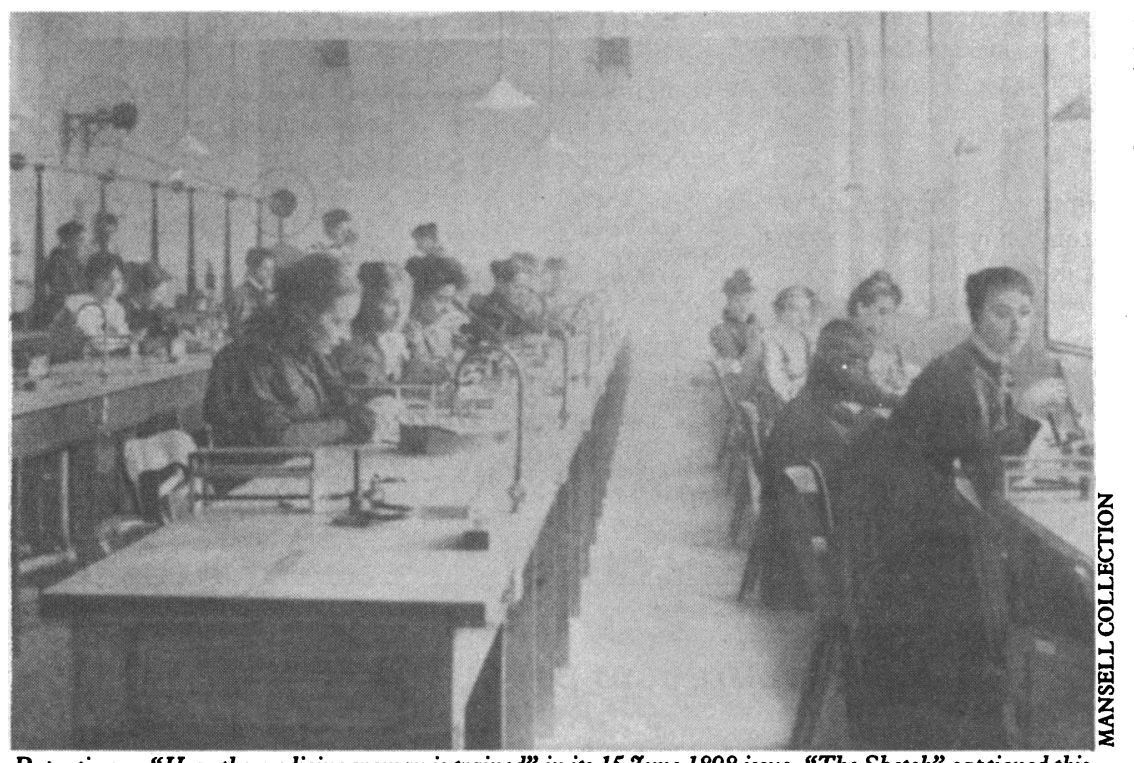

Reporting on "How the medicine woman is trained" in its 15 fune 1898 issue, "The Sketch" captioned this photo, "How lovely woman toils in a laboratory"

dedicated to the training of women. Elizabeth Garrett Anderson herself made mention of the great sum of $£ 12000$, which had been raised as an endowment for this school. Equally important, in 1876 Russell Gurney's Enabling Bill, which permitted licensing bodies to examine women, was made law. Such milestones ensured that there were greater opportunities for women to become qualified medical practitioners, regardless of being allowed to join the BMA.

Elizabeth Garrett Anderson completed her talk by dismissing the question of a loss of modesty in discussing medical matters between the sexes, ridiculing her male colleagues who "find it impossible, without a shock to their moral refinement and sense of delicacy, to discuss pleuritic effusions in the presence of a woman." She declares robustly, "I am not aware of anything in the whole range of general medicine or gynaecology which I could not discuss with practitioners of medicine without any sense of embarrassment."

She concluded with a rousing affirmation of the founding principles of the British Medical Association, underlining the importance of "keeping true to its largest purposes, which in our case are the promotion of science and the promotion of fellowship." She illustrated the fallacy of intolerance with the story of Charles Lamb, who was pulled up by his friend for heaping abuse on the head of a man whom he did not know. Lamb retorted: "My dear fellow, of course, I do not know him. How could I hate him at all if I did?" Elizabeth Garrett Anderson on this principle exhorted her fellow members to "let your prejudices melt away."

Her speech was received rapturously; Mr Barrow who followed on from this "confessed that, if anything could have made him change his views upon this subject, it would have been the very pleasing address of Mrs Anderson. There was no member of the Association but would be happy to meet Mrs Anderson in society, at dinner or in general meeting." Favourable impressions notwithstanding, however, the vote to add a clause excluding women was passed by "an unquestionable majority."'

There followed a period of intense isolation for Elizabeth Garrett Anderson; despite her solitary status as the only woman member of the BMA, she continued to go to branch, division, and annual meetings and usually spoke at such occasions, but she confessed to her husband that "Sometimes the feeling of disapproval becomes almost unbearable." ${ }^{3}$ However, changes in the training and registration of women were slowly having their effect on the medical establishment.

\section{The debate revived}

It was not until 1892 that the question was debated again at the Nottingham annual meeting. An extraordinary general meeting was held on 28 July 1892 and Dr Galton moved to expunge the clause of the articles of the association excluding women for the sake of the "efficiency and harmony" of the association. He stated that whereas in 1878 there were only eight practising women doctors "who had gallantly struggled through the various portals into the profession" there were 135 women doctors in 1892: "times were changed and were, he hoped, changed for good." Dr Galton then made a vitriolic attack in fullblown rhetoric on "this gutter policy" and those supporting it: "It was unworthy of it [the association] and of their profession when its great leaders adopted such a policy, and showed that their ill-fitting garments hung upon them like full-grown clothes upon the shrunken shanks of a pantaloon."

His motion was seconded by Elizabeth Garrett Anderson, who made a fairly low-key speech echoing the themes of her earlier address in 1878. She emphasised the need to create a feeling of "solidarity" within the profession and, like Dr Galton, underlined the fact of the existence of 135 practising women doctors as in itself a compelling argument for their inclusion into the association. She concluded with an appeal to fellow members: "They were all disciples of Darwin and his great theory of evolution, and here before their eyes was the great evolution of women out of one stage into another, and if they were all really good Darwinians they would help this evolution."

This point was reinforced by the next speaker, $\mathrm{Mr}$ Brown, who betrayed the conflicts and tensions inherent in the movement to "enfranchise" women doctors. He stated that "they had now arrived at a time when the evolution of women demanded that their position be recognised in the medical profession" despite the fact that "there was no one who at the Bath meeting worked harder to oppose the resolution for their admission that he did ... he still thought it would be very much better for women themselves if women were not in the profession. He thought himself that he could do the work of a surgeon or of an obstetrician very much better than any woman who had ever tried.' However, he lent his support to the admission of women, albeit grudgingly: "Let them see what women could do. He felt sure that they could not do much harm."

\section{The 1892 decision}

A vote was then taken, and the resolution carried by 297 to 4 to admit women to the association. This was later contested by the vice president of the BMA, Dr Holman, who wrote to the British Medical Fournal on 13 August 1892 "to record my emphatic protest against a hasty legislation by which a radically organic change in our laws is sought to be confirmed on August 24th, a date when so many medical men are compelled to be absent on their hardly-earned holidays." ${ }^{\text {" Notwith- }}$ standing this protest, the decision to admit women doctors was confirmed in August 1892.

In 1896 the East Anglian branch of the British Medical Association elected Elizabeth Garrett Anderson as its president. Women-or, more accurately, a woman - had stormed the innermost sanctuaries of medical politics. The military analogy-one which Anderson herself would have eschewed-was adopted earlier by the Lancet in describing the training of women in medical schools. 
"A lady has penetrated to the core of our hospital system, and is determined to effect a permanent lodgment. The advanced guard of the Amazonian army which has so often threatened our ranks, on paper, has already carried the outposts and entered the camp."'

The admission of women into the British Medical Association marked an important stage in the enfranchisement of women in medicine. The part played by Elizabeth Garrett Anderson was significant, as the essentially conservative pioneer who represented the acceptable face of practising women doctors to the (male) profession. Indeed, the shift in policy by the profession - if it can be seen as a concerted or collective endeavour at all-was characterised by the forces of circumstance and a desire to control the marginal forces of unregulated doctors, whatever their sex. In the debate a hundred years ago on the admission of women to the association, the march of progress was tempered by pragmatic self interest, a combination without which no revolution is guaranteed success.

1 Forty-six annual meeting of the British Medical Association. BMF 1878:ii:253. 2 Muirhead-Little E. History of the BMA. Vol I. 1832-92. London: British Medical Association, 1932

3 Anderson L G. Elizabeth Garrett Anderson. London: Faber, 1939.

4 Blake C. The charge of the parasols: women's entry to the medical profession. London: Women's Press, 1991.

5 Admission of ladies to meetings of the British Medical Association. BMf $1878 ; \mathrm{i}: 175$.

6 The admission of ladies to the British Medical Association [editorial]. BMF 1878;i:234

7 Extraordinary general meeting. BMf 1892;ii:262.

8 The admission of women to the association. $B M I^{\prime} 1892 ;$;i: 383 .

9 A lady amongst the students. Lancet $1861 ;$ ii: 16 .

\section{Princess Vera Gedroits: military surgeon, poet, and author}

\section{J D C Bennett}

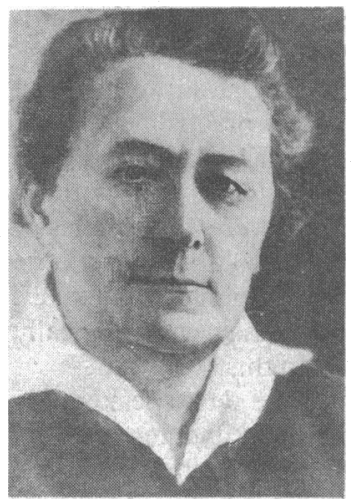

Princess Vera as professor of surgery in Kiev, a post she held from 1929 to 1932

Department of Ear, Nose, and Throat Surgery,

Queen Elizabeth Military

Hospital, London

SE18 4QH

J D C Bennett, senior

specialist
$B M f$ 1992;305:1532-4

The name of Princess Vera Gedroits is now no more than an obscure reference in old surgical textbooks, but her story deserves to be told.

She was born in Kiev on 7 April 1876 and her family lived on an estate in Slobodishche in the district of Bryansk. As was the custom, her early education was at home, followed by finishing school in St Petersburg. Well before the 1905 revolution the city was the scene of various underground organisations. Vera took part in the illegal meetings of V A Veinshtok, but after this circle was broken up in 1892 she was sent back home to remain under police supervision. She managed a reprieve and made for Switzerland, a favourite refuge for women from Russia who wanted to study medicine. ${ }^{2}$ She studied medicine in Lausanne, completing her studies in 1898 at the age of 22 , obtaining almost a complete set of top marks in her final examinations. Perhaps still wary of being tracked down, she had three different addresses in three terms and altered her name. ${ }^{3}$

After qualification Vera worked for a while in Professor Roux's clinic but did not settle, returning to Russia in 1900. In 1904 only 3.4\% of Russian doctors were women. ${ }^{4}$ She published a variety of medical papers but because of her previous connections she came under the attention of the police (the dreaded Okhrana). Possibly because of this and from a sense of adventure she volunteered as a surgeon for a hospital

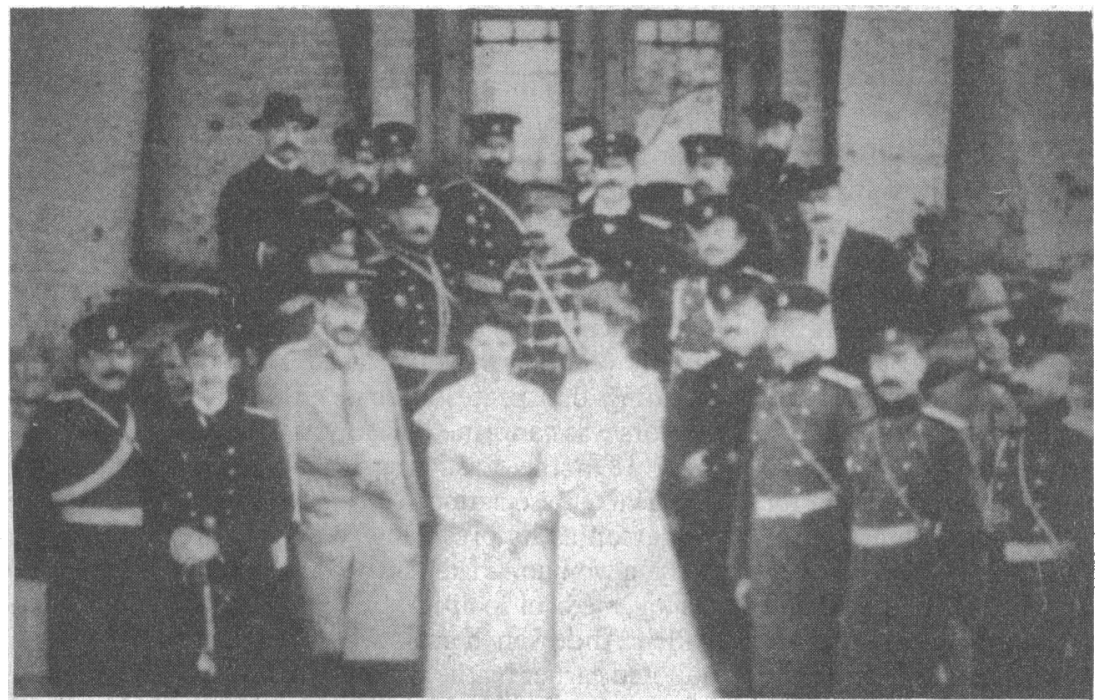

Princess Doctor Vera Gedroits (right) in the company of officers of the Imperial Army (probably 1904-5) train organised by the Red Cross. This supplemented the Russian army's medical department and was well supported by wealthy Russians, acting partly through altruism or possibly for the hope of some reward. The central committee was in St Petersburg and under the patronage of the empress, who not only ensured that the staff was chosen from the city's best surgeons but also gave over rooms in the Winter Palace for sewing bandages.

The War Office's report on the Russo-Japanese war said of Vera:

Among those who went to the Front in the service of the Red Cross as surgeons [was] the Princess Gedroits, chief surgeon of the hospital train furnished by the associated nobility of 40 Russian "governments," who was always at the front, operating in a specially constructed car, till the enemy's fire threatened the train.

This was no small risk. Dr Marcou, physician to the Troitzky Hospital, St Petersburg, cynically wrote of the field ambulances that "the most notable result of their employment has been that not a few of the medical officers in charge of them have been killed in action." "In this they were perhaps not best served by the instructions for the Russian army: "Military ambulances and hospitals are recognised to be neutral only so long as sick and wounded may be therein. Their neutrality ceases if they are defended by a military force."

The conclusions of the joint reports written at the end of the war were that healthy fit troops fighting under modern conditions could expect a minimum annual rate of wastage through wounds or illness among the field army of $55 \%$, exclusive of prisoners. ${ }^{5}$ It is hard to see where the optimism with which the protagonists approached the first world war eight years later was based. The infantry of the lst army lost $96.7 \%$ of its officers and $67 \%$ of its men as killed and wounded during the first 13 months of the war. These figures were the result of the widespread use of modern destructive instruments of war, in particular the machine gun. The surgeons lost 12 of their number (two killed, seven missing, and three suicides) and 21 were wounded; 28 were taken prisoner, of whom 20 were subsequently released by the Japanese.

Vera presented the results of her work to the Society of Military Doctors on 27 July 1905, making the following points, all of which have current military relevance. The closer a hospital was to the battlefield the more productive was its work, and such a hospital could look after those patients who would be returned 